Génét. Sél. Evol., 1984, 16 (1), 45-56

\title{
Population crash, population flush and genetic variability in cage populations of Drosophila melanogaster
}

\author{
F.A. LINTS and M. BOURGOIS \\ Laboratoire de Génétique, Université de Louvain \\ 2, place Croix-du-Sud, B 1348 Louvain-la-Neuve (Belgium)
}

\begin{abstract}
Summary
A large increase in the total phenotypic variance of thorax size was observed in a cage population of Drosophila melanogaster, maintained at $28^{\circ} \mathrm{C}$, a few months after it had been the victim of a naturally occuring population crash, the number of individuals in the population having, at a given moment, been reduced to half a dozen. In order to ascertain whether that increase in total phenotypic variance was due to an increase in environmental or in genetic variance that population was submitted, together with five other normally developing cage populations, to a selection programme for high and low bristle number. The additive genetic variance of these various populations was thereafter estimated. The additive genetic variance of the $28^{\circ} \mathrm{C}$ cage population, victim of a population crash, was found to be highly significantly larger than all the other ones. The consequences of that unexpected observation on the theories of evolution are discussed. It is argued that that result confirms some of the predictions of the genetic revolution (genetic transilience) hypothesis of speciation.
\end{abstract}

Key words : Drosophila melanogaster, cage populations, genetic variance, speciation, genetic revolution hypothesis, sternopleural bristles.

\section{Résumé}

Changements d'effectifs et variabilité génétique dans des cages à population chez Drosophila melanogaster

Un accroissement important de la variance phénotypique totale de la taille thoracique a été observé dans une cage à population de Drosophila melanogaster quelques mois après que cette population ait été victime d'une réduction drastique et naturelle du nombre d'individus qui la composait, ce nombre ayant été réduit à environ une demi-douzaine d'individus. Cet accroissement brutal de la variance phénotypique totale pouvait être dû à un accroissement, soit de la variance due à l'environnement, soit de la variance génétique. De manière à résoudre cette alternative, cette population a été soumise à une sélection bidirectionnelle pour le nombre de soies sternopleurales de concert avec cinq autres populations qui s'étaient développées normalement dans des cages à population dans diverses conditions d'environnement. Il a dès lors été possible d'estimer la variance génétique additive 
de ces diverses populations. Il est montré que la variance génétique additive de la population victime d'une réduction drastique de ses effectifs est de loin supérieure à celle de toutes les autres populations observées. Les conséquences de cette observation inattendue sur les théories de l'évolution sont débattues. Les auteurs estiment que ce résultat confirme un certain nombre des prédictions émises par les théoriciens de l'hypothèse sur la spéciation dite hypothèse de la révolution génétique (hypothèse de la transilience génétique).

Mots clés : Drosophila melanogaster, cages à population, variance génétique, spéciation, hypothèse de la révolution génétique, soies sternopleurales.

\section{Introduction}

It has generally been assumed that speciation is the result of a gradual and slow genetic divergence brought about by different selection pressures acting on ecologically isolated populations. For some time however a few authors (CARSON, 1971, 1975 ; TeMPleton, 1980 a ; Jones, 1981) have been claiming that speciation could also be due to a so-called "genetic revolution " caused by random processes acting on very small isolated populations. That idea of genetic revolution originates from the so-called «founder's principle» proposed by MAYR as early as 1942. MAYR defines it as referring to «the establishment of a new population by a few original founders... which carry only a small fraction of the total genetic variation of the parental population».

MAYR's theory of the founder's principle and of the ensuing genetic revolution thus admits that the few original founders of a new population possess only a part of the genetic variability to be found in the population from which the founders originated. Afterwards that reduced genetic variability may be even further reduced because of the consequences of the random drift which is a direct function of the reduced size of a population. More specifically MAYR (1954) argued that the founder effect and its associated inbreeding would affect «all loci at once».

The question then arises how a new, large, normal and eventually diverging population may spring up from a single or a few founder individuals. MAYR (1954) has suggested that as a result of the increased frequency of homozygotes in the founder population selection against certain genes will increase. The "genetic environment " will be changed so as to modify radically the selective value of a large number of loci up to the point where the system reaches a new state of equilibrium. In other words, the hypothesis holds that if colonization is accomplished by a single or a small number of founders the breaks in the gene pool may be significant enough to result in a drastic reconditioning of the gene pool of the new colony resulting in a genetic revolution.

More or less in the same line of thinking CARson (1971) believes that «when a population derived from a single founder expands, the loss of genetic variability expected through random drift can be expected to be temporary and can be compensated for by new mutations ». Jones (1981), reviewing the models of speciation, ascribes the renewal of genetic variability to the fact that by invading previously unexploited ecological niches the founders may undergo an enormous increase in number, the population flush. The consequence of that flush is a relaxation of selection against deviant individuals which will further favour the success of the genetic revolution. 
Templeton (1980 a and b) admits that a founder effect can induce rapid speciation but does not believe that the speciation is mediated by extensive changes throughout the genome (MAYR's genetic revolution). His theory, which he prefers to call genetic transilience rather than genetic revolution, is indeed based upon just the opposite assumption : «A genetic transilience does not shake-up the whole genome ; rather it is confined principally to a polygenic system strongly affecting fitness that is characterized by having a handful of major genes with strong epistatic interactions with several minor genes»(TEMPLEToN, $1980 \mathrm{a}$ ). Noteworthy in TemPleton's theory is the fact that if there are indeed a few major genes implied in the genetic transilience then the stochastic effects of the founder event cannot be ignored. In other words not all founder events - and indeed perhaps only a minority of these events - will lead to speciation via the genetic transilience model (Templeton, $1980 \mathrm{~b}$ ).

According to TEMPLETON (1980 b) for genetic transilience to occur the changes in the genetic selection environment must be so drastic that a selection bottleneck is engendered; this may occur if the change in the effective sizes of the ancestor and the founder populations is large. The chance of the founder population to survive and to respond to that selection bottleneck will then depend upon the level of genetic variability present in the founder population. In that respect Rose (1982) has suggested that genetic systems characterized by much epistasis and pleiotropy can maintain large amounts of genetic variation; he further argued that when such systems are dirsupted - as they could be in Templeton's model, first through the founder effect, then by the effects of recombination during the population flush - such systems can release large amounts of additive genetic variance.

Despite these theoretical speculations, there are still questions which have not yet received a proper experimental answer. For instance, there is no experimental evidence about the increase, decrease or stability of the genetic variability in a population issued from a small founder population. Nor about the environmental conditions which may eventually further that genetic variability.

We were able, a few months after their foundation, to estimate and compare the genetic variability of various cage populations, maintained for a few months at different temperatures and issued either from a small or a large number of founder individuals. Although in a preliminary stage, these observations confirm some of the predictions of the genetic revolution hypothesis and suggest that adverse environmental conditions may further genetic variability in a very short time.

\section{Material and methods}

Two strains of Drosophila melanogaster were used : the wild laboratory strain, Oregon, previously maintained in our laboratory, at $25^{\circ} \mathrm{C}$, for at least fifteen years and the Bonlez strain, started from flies captured in the wild (in Belgium) fourteen months before the experiments. In January 1979 three times 60 pairs of flies of the Oregon strain were placed in population cages at $21^{\circ}, 25^{\circ}$ and $29^{\circ} \mathrm{C}$, respectively. The $21^{\circ}$ and $25^{\circ} \mathrm{C}$ populations expanded rapidly in number and attained, after a few weeks, a stable population size of about 1000 to 1500 flies. The $29^{\circ} \mathrm{C}$ population eventually died out. An attempt was then made at $28^{\circ} \mathrm{C}$; the population size 
remained very low for a few months and, in September 1979, was even low as half a dozen flies; afterwards, in a few weeks, it increased rapidly in number and became stabilized. Concerning the Bonlez strain 40 inseminated females of Drosophila melanogaster were captured in Bonlez (Belgium) in July 1979; they were allowed to multiply and their offspring were divided in three groups which were transferred in half pint milk bottles at $21^{\circ}, 25^{\circ}$ and $28^{\circ} \mathrm{C}$.

\section{Results}

In April 1980, from the eggs collected in the three population cages (Oregon populations) and in the three culture bottles (Bonlez populations), the thorax size of samples of 50 females and 50 males was measured and the mean size and the variance of the size were calculated (tabl. 1).

\section{TABLE 1}

Mean thorax size (mms) and variance of the thorax size $\left(\times 10^{6}\right)$ of females $(n=50)$ and males $(n=50)$ of three populations of both the Oregon and the Borlez strains.

Moyenne et variance de la taille du thorax chez les femelles et les mâles de 3 populations des souches Oregon et Bonlez.

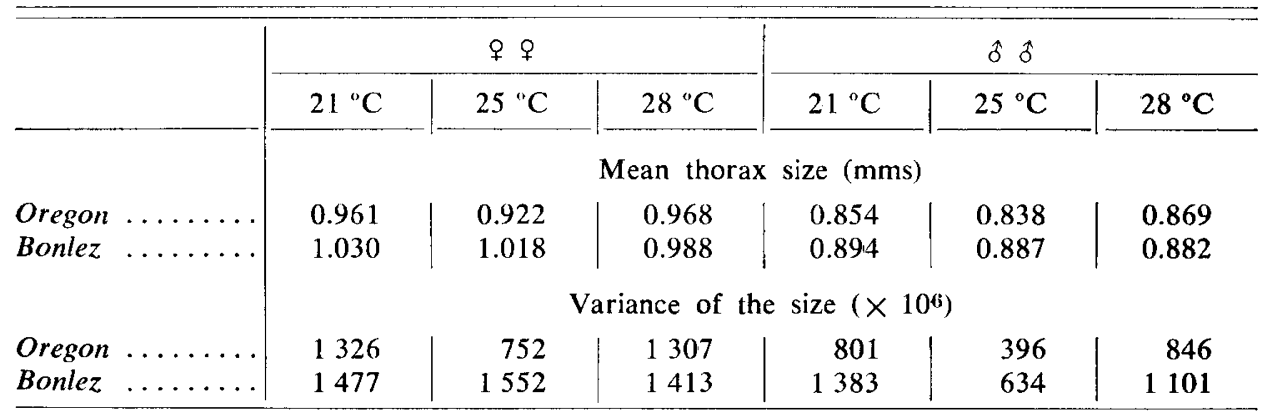

The measured flies were all grown at $28^{\circ} \mathrm{C}$.

Les mouches mesurées ont toutes été élevées à $28^{\circ} \mathrm{C}$.

Two important facts emerge from these results. First : the variance of the size is, on average, larger in the Bonlez strain than in the Oregon strain; this, most probably, reflects the past history of these two strains, Oregon having been adapted for fifteen years at a constant temperature of $25^{\circ} \mathrm{C}$ and Bonlez being a freshly captured wild strain .Second : the variance of the thorax size of the $28^{\circ} \mathrm{C}$ and $21^{\circ} \mathrm{C}$ Oregon populations is significantly larger than the variance of the $25^{\circ} \mathrm{C}$ population. (It must be reminded that the original Oregon strain had been maintained at $25^{\circ} \mathrm{C}$ for at least fifteen years). 
The higher variability of the $28^{\circ} \mathrm{C}$ and $21^{\circ} \mathrm{C}$ Oregon populations points either to a higher genetic or to a higher phenotypic variability. In order to discriminate between these two possibilities a two-way selection experiment was undertaken. Indeed such an experiment allows one to estimate, for a particular trait, the additive genetic variance present in the population. The trait chosen was sternopleural bristle number : the heritability of that trait is, in general, quite large and, as shown by some preliminary measurements (tabl. 2) the phenotypic expression of the character is almost insensitive to the effects of developmental temperature.

\section{TABLE 2}

Means and variances of sternopleural bristle number in the six populations measured. Moyennes et variances du nombre de soies sternopleurales dans les 6 populations mesurées.

\begin{tabular}{|c|c|c|c|}
\hline Population & $21^{\circ} \mathrm{C}$ & $25^{\circ} \mathrm{C}$ & $28^{\circ} \mathrm{C}$ \\
\hline & \multicolumn{3}{|c|}{ Sternopleural bristle number } \\
\hline $\begin{array}{l}\text { Oregon } \ldots \ldots \ldots \ldots \\
\text { Bonlez } \ldots \ldots \ldots \ldots\end{array}$ & $\begin{array}{l}20.6 \\
20.9\end{array}$ & $\begin{array}{l}21.0 \\
18.5\end{array}$ & $\begin{array}{l}21.0 \\
19.7\end{array}$ \\
\hline & \multicolumn{3}{|c|}{ Variance of bristle number } \\
\hline $\begin{array}{l}\text { Oregon } \ldots \ldots \ldots \ldots \ldots \ldots \ldots \\
\text { Bonlez } \ldots \ldots \ldots \ldots \ldots \ldots\end{array}$ & $\begin{array}{l}4.02 \\
2.90\end{array}$ & $\begin{array}{l}2.71 \\
3.65\end{array}$ & $\begin{array}{l}7.08 \\
5.23\end{array}$ \\
\hline
\end{tabular}

Data for males $(n=48)$ and females $(n=48)$ are pooled. Each population is grown at the temperature at which it was kept during the preceding period of time.

Les données des mâles $(n=48)$ et des femelles $(n=48)$ sont regroupées. Chaque population est maintenue à la même température que celle appliquée durant la phase précédente.

The characteristics of the Oregon and Bonlez populations before the selection experiment began are given in table 2, which shows that the variance of bristle number of the $28{ }^{\circ} \mathrm{C}$ Oregon population is remarkably high; it is significantly larger $\left(\mathrm{P}<0.001\right.$ or $<0.01$ ) than all the other variances except the one of the $28^{\circ} \mathrm{C}$ Bonlez population. The variance of bristle number of the Oregon $21^{\circ} \mathrm{C}$ population is also significantly higher than that of the Oregon $25^{\circ} \mathrm{C}$ population. In the six populations where selection for bristle number was made, 48 females and 48 males were measured for sternopleural bristle number, at each generation, both in a high and a low line. 12 lines were thus created. The 12 females and the 12 males with the highest and lowest bristle numbers were kept for reproduction. The selection was continued for four generations. The results of that selection experiment are given in figure 1 and tables 3 and 4 : the cumulated selection differentials and the cumulated responses are given in table 3 ; the realised heritabilities (see fig. 1 B) and the estimated additive genetic variances for the six populations tested are given in table 4 .

The selection differentials are not very different from one population to the other; they are however higher at $28{ }^{\circ} \mathrm{C}$ than at the other temperatures, especially for the Oregon strain. The cumulated responses are, on the average, smaller for the Bonlez strain than for the Oregon strain. In the Oregon strain the cumulated response at $25^{\circ} \mathrm{C}$ is small - of the same order of magnitude as the responses of the Bonlez strain - ; it is larger at $21^{\circ} \mathrm{C}$ and much larger at $28^{\circ} \mathrm{C}-$ more than twice the response at $25^{\circ} \mathrm{C}$ - 
A.
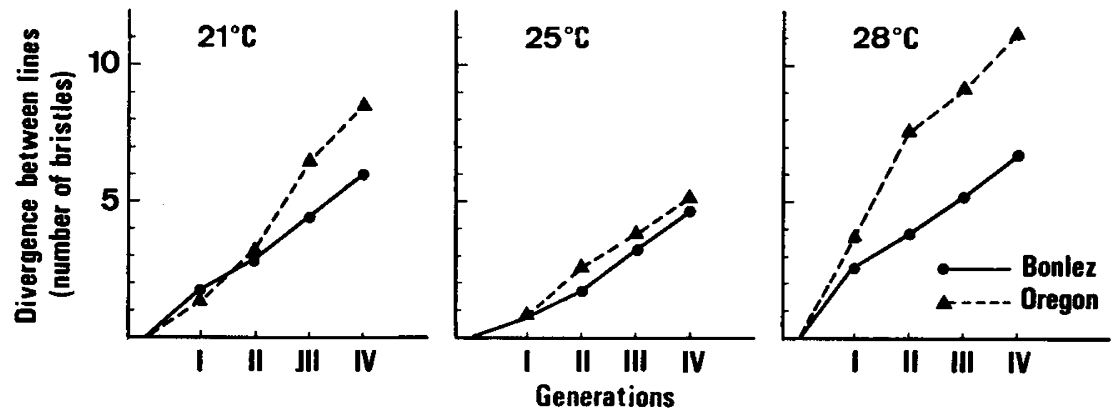

B.
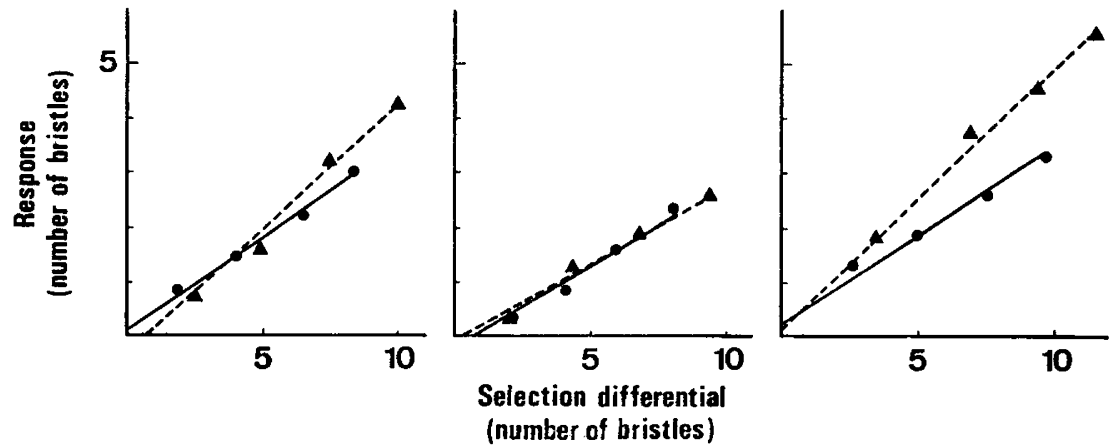

(number of bristles)

FIG. 1

A

Divergences between the high and low lines of selection for bristle number in the Oregon and Bonlez populations.

Ecarts entre les lignées haute et basse de sélection pour le nombre de soies sternopleurales dans les populations Oregon et Bonlez.

(The selections were made at $21^{\circ}, 25^{\circ}$ and $28^{\circ} \mathrm{C}$, i.e. at the temperatures at which the populations were kept during the preceding period of time.)

(La sélection a été effectuée à $21^{\circ}, 25^{\circ}$ et $28^{\circ} \mathrm{C}$, soit aux températures d'élevage de la phase précédente.)

\section{B}

Cumulated responses plotted against the cumulated selection differentials.

Réponses cumulées à la sélection en fonction des écarts de sélection cumulés.

(The responses and selection differentials in the high and low lines being symmetrical in all the populations observed, the figures given are means.)

(Les réponses à la sélection et les écarts de sélection étant symétriques dans les lignées haute et basse, les chiffres présentés sont des moyennes.) 
TABLE 3

Cumulated selection differential and cumulated response (in number of bristles) for the Oregon and Bonlez strains selected for high and low sternopleural bristle number at three temperatures.

Ecart de sélection cumulé et réponse à la sélection cumulée chez les souches Oregon et Bonlez soumises à une sélection deux-voies pour le nombre de soies sternopleurales à 3 températures d'élevage.

\begin{tabular}{|c|c|c|c|c|c|c|}
\hline & \multicolumn{3}{|c|}{$\begin{array}{l}\text { Cumulated selection differential } \\
\text { (number of bristles) }\end{array}$} & \multicolumn{3}{|c|}{$\begin{array}{l}\text { Cumulated response } \\
\text { (number of bristles) }\end{array}$} \\
\hline & $21^{\circ} \mathrm{C}$ & $25^{\circ} \mathrm{C}$ & $28^{\circ} \mathrm{C}$ & $21^{\circ} \mathrm{C}$ & $25^{\circ} \mathrm{C}$ & $28^{\circ} \mathrm{C}$ \\
\hline Oregon & & & & & & \\
\hline $\begin{array}{l}\mathbf{F}_{1} \ldots \ldots \ldots \ldots \\
\mathbf{F}_{2} \ldots \ldots \ldots \ldots \\
\mathbf{F}_{3} \ldots \ldots \ldots \ldots \\
\mathbf{F}_{4} \ldots \ldots \ldots \ldots\end{array}$ & $\begin{array}{l}2.5 \\
4.9 \\
7.4 \\
9.9\end{array}$ & $\begin{array}{l}2.0 \\
4.3 \\
6.8 \\
9.4\end{array}$ & $\begin{array}{r}3.4 \\
6.9 \\
9.4 \\
11.5\end{array}$ & $\begin{array}{l}0.7 \\
1.6 \\
3.2 \\
4.2\end{array}$ & $\begin{array}{l}0.3 \\
1.3 \\
1.9 \\
2.6\end{array}$ & $\begin{array}{l}1.9 \\
3.8 \\
4.5 \\
5.6\end{array}$ \\
\hline Bonlez & & & & & & \\
\hline 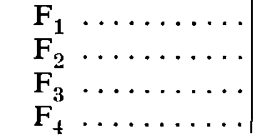 & $\begin{array}{l}1.9 \\
4.0 \\
6.4 \\
8.3\end{array}$ & $\begin{array}{l}2.2 \\
4.0 \\
5.9 \\
8.0\end{array}$ & $\begin{array}{l}2.7 \\
5.1 \\
7.6 \\
9.8\end{array}$ & $\begin{array}{l}0.9 \\
1.4 \\
2.2 \\
3.0\end{array}$ & $\begin{array}{l}0.3 \\
0.9 \\
1.6 \\
2.3\end{array}$ & $\begin{array}{l}1.3 \\
1.9 \\
2.6 \\
3.3\end{array}$ \\
\hline
\end{tabular}

Since both the selection differential and the response were symmetrical in the high and low lines in all the populations observed, the figures provided are means.

Les écarts et les réponses étant symétriques dans les lignées haute et basse, les chiffres qui sont présentés sont des moyennes.

\section{TABLE 4}

\section{$A$}

Realised heritability of sternopleural bristle number in the six populations tested, estimated by the coefficient of regression of the cumulated response to selection on the cumulated selection differential.

Héritabilité réalisée du nombre de soies sternopleurales dans les 6 populations contrôlées estimée par le coefficient de régression de l'écart de sélection cumulé sur la réponse cumulée à la sélection.

\section{$B$}

Additive genetic variance of sternopleural bristle number in the six populations tested, estimated by the product of the realised heritability and of the variance present in the base populations.

Variance génétique additive du nombre de soies sternopleurales dans les 6 populations contrôlées estimée par le produit de l'héritabilité réalisée et de la variance observée dans les populations initiales.

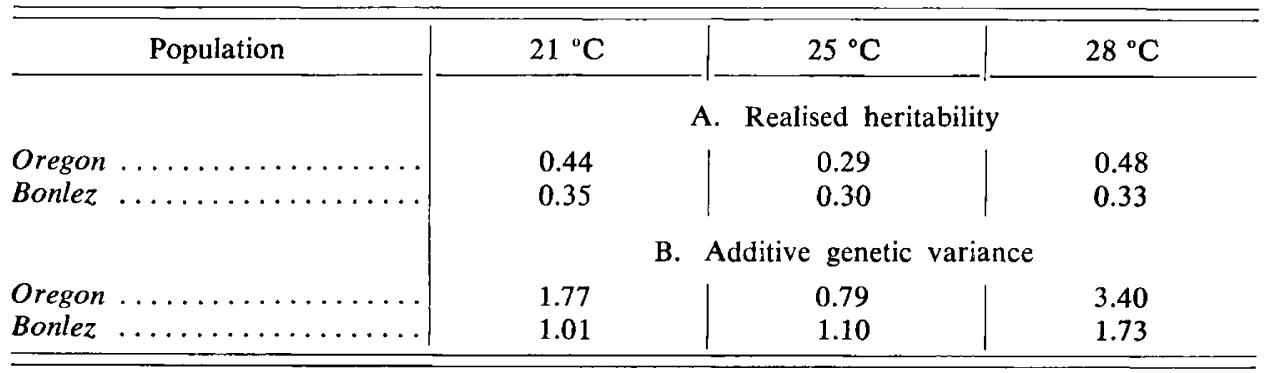


The realised heritabilities (i.e. the coefficient of regression of the cumulated response on the cumulated selection differential) in the three Bonlez populations are similar. In the Oregon strain, for the $25^{\circ} \mathrm{C}$ population, it is of the same order of magnitude as the ones of the Bonlez strain; it is however higher in the $21^{\circ} \mathrm{C}$ population and maximal in the $28^{\circ} \mathrm{C}$ population. The realised heritabilities of Oregon $28^{\circ} \mathrm{C}$ and Oregon $21^{\circ} \mathrm{C}$ are significantly larger than the one of Oregon $25^{\circ} \mathrm{C}$.

Finally the additive genetic variance, which may be estimated by the product of the realised heritability and of the total variance present in the base population is the largest in the $28^{\circ} \mathrm{C}$ Oregon population; it is in fact almost twice as large as the nearest value observed in the $21{ }^{\circ} \mathrm{C}$ population.

These results indicate that the high variabilities of the $28{ }^{\circ} \mathrm{C}$ and $21{ }^{\circ} \mathrm{C}$ Oregon populations are, at least partly, due to a high genetic variability present in these populations. The genetic variability of the $28^{\circ} \mathrm{C}$ population, issued from a very small number of founder individuals, and submitted to highly adverse environmental conditions is the largest of the six populations tested. The variability of the $21^{\circ} \mathrm{C}$ Oregon population, submitted to conditions radically different from those that the original Oregon strain had been submitted to for fifteen years, is also very high.

\section{Discussion}

The appearance of a genetic novelty, i.e. a new species, an incipient species or a population diverging from the population from which it originated, has been attributed either to natural selection (DowDESwELl \& FORD, 1952, 1953; FORD, 1954), to random drift (DoBZHANSKY, 1941) or to a mixture of both these factors (Dobzhansky \& PaVlovsky, 1957).

These different opinions on the genetic evolution of populations derived from a few founders mainly take into account the genetic variability which is originally present in the founders and which, until recently, has been believed to be smaller than the genetic variability present in the population from which the founders originated. However, the emergence of a well adapted species or population with new genetic characteristics from a small founder population implies both an important genetic variability, on which natural selection may act, and certain genetic novelties, which are a source of new qualities. That genetic variability may stem, either from a relaxed or modified selection pressure (CARSON, 1971 ; JoNES, 1981), or, as suggested by recent experimental evidence and theoretical speculations (ANNEST \& TEMPleton, 1978 ; Templeton, $1980 \mathrm{a}$ and $\mathrm{b}$; Rose, 1982) from a creative disruption of the genetic system of the founder individuals.

Does such variability exist? As far as we know, and curiously enough, no one has searched for it. In fact at the root of most speculations are observations either of divergent - not diverging ! - populations or of new species (see, for instance, the observations of CARson's school on the Drosophila fauna of the Hawaiian archipelago. Carson \& Kaneshiro, 1976; Kaneshiro, 1980). Exemplary too are the efforts made to show the existence of sexual isolation in experimental populations (see, for instance, in recent years, Powell, 1978 ; Templeton, 1979 ; Ahearn, 1980). 
Although it appears conceivable that in a large population the appearance of sexual isolation may be at the origin of evolutionary divergence, it appears highly probable that in the case of diverging isolated populations, issued from small founder populations, genetic divergence does not need to start with sexual isolation. This last point was clearly shown by the study of genetic differentiation during the speciation process in the Drosophila willistoni group of species (Ayala et al., 1974). And indeed the Oregon and Bonlez populations were tested for sexual isolation; no sign of it could be brought to the fore.

The present experiments show that very soon after a population has suffered a severe bottleneck the resulting new population (Oregon $28^{\circ} \mathrm{C}$ ) displays a very high genetic variability, larger than the one present in the original population (Oregon $25^{\circ} \mathrm{C}$ ). Where does that variability come from ? It is not impossible that mutant individuals, which, in normal breeding conditions, would normally be eliminated by natural selection, may survive during the period of population expansion which follows the bottleneck. MuKaI (1964) has estimated that, in Drosophila, at least 5 p. 100, and maybe 35 p. 100 , of the gametes carry a new mutation. An alternative possibility is that that variability was present among the founder individuals and that it was very rapidly released, according to the suggestions made by TEMPLETON $(1980 \mathrm{~b})$ and by Rose (1982), first through the founder effect and then through the effects of genetic recombination occuring during the population flush. The present evidence does however not discriminate between these alternatives.

Now all the variations in genetic variability disclosed in our experiments cannot be explained by the effects of a bottleneck followed by a population flush. If it were Oregon $21^{\circ} \mathrm{C}$ should not be more variable than Oregon $25^{\circ} \mathrm{C}$, since none of these two populations suffered a bottleneck. Yet Oregon $21^{\circ} \mathrm{C}$ is almost as variable as Oregon $28{ }^{\circ} \mathrm{C}$ and, anyway, much more than Oregon $25^{\circ} \mathrm{C}$. For the last fifteen years the Oregon strain was maintained, at $25^{\circ} \mathrm{C}$, in environmental conditions that caused severe natural selection. The population cage breeding, at $25^{\circ} \mathrm{C}$, should not sensibly affect the well-adapted Oregon $25^{\circ} \mathrm{C}$ population. On the other hand the modification of the ecological conditions caused by the sudden transfer from $25^{\circ} \mathrm{C}$ to $21^{\circ} \mathrm{C}$ may eventually lead to the generation of new genetic variance, for example, by a modification of the selective values of many genes.

The genetic variabilities of the three Bonlez populations, although similar, increase slightly between $21^{\circ} \mathrm{C}$ and $28{ }^{\circ} \mathrm{C}$. It may be recalled that these three populations directly derive from a wild population, which, by definition, is submitted to variable ecological conditions. In such a population the genetic variability must be important and the selective values must be variable. Considering the Bonlez data in the light of the present results, it is however not surprising to notice that the genetic variability is the largest at $28^{\circ} \mathrm{C}$, the environment which is the most unusual to a wild strain.

The present data show that a population reduced to a very small number of individuals either can rapidly restore or can maintain a great deal of genetic variability. They also show that such a population can diverge genetically from the population it was started from. They finally show that adverse environmental conditions may also lead to the generation of an important genetic variability. It must be stressed that the existence of a large amount of genetic variability in the population which had suffered a severe bottleneck was observed less than seven months after the bottleneck occured, a rather surprising and at least unusual observation. In that respect it may 
however be reminded that most, if not all, studies looking at differences arising in population cages of identical origin submitted to various environmental conditions have been started a few years after isolation (see, for instance, EHRMAN, 1964 ; Mourad, 1965 ; ANDERSON, 1966).

It is clear that the present observations and measurements should be multiplied. They should also be done just after the bottleneck, during the flush phase, and at regular intervals during the phase of stability. Yet it will be a difficult task to multiply the present observations. Indeed in a population cage a naturally occuring bottleneck is not an ordinary phenomenon. Creating a bottleneck by starting a population cage with a very few randomly choosen individuals will probably not mimic a naturally occuring bottleneck where the few surviving individuals most probably survive because of their exceptional phenotype.

Now, suppose that bottlenecks can be multiplied. If, in all cases the founders individuals survive and a large genetic variability is observed during the phase of stability, this could be used as an argument in favour of the genetic revolution hypothesis of speciation. On the opposite if only a (non definable ?) fraction of the bottleneck populations survive this could, eventually, be used as an argument in favour of the genetic transilience theory of speciation. Furthermore it is not impossible that the time of onset of the increase in genetic variability, as observed in the present experiment, may be different as a function of the reality of the one or the other hypothesis. May we suggest that the tenants of both these hypotheses specify their views on these questions!

Received February 11, 1983.

Accepted July 29, 1983.

\section{Acknowledgements}

This work was supported by the U.S. N.I.H. AG 02087 grant to F.A.L. M.B. was a fellow of the I.R.S.I.A. This paper was written at the Department of Agricultural Botany of the University College of Wales at Aberystwyth where one of us (F.A.L.), at the kind invitation of Professor H. ReEs, was appointed Visiting Professorial Fellow. Many thanks are due to $\mathrm{D}^{\mathrm{r}} \mathrm{N}$. JoNES (Aberystwyth) for a critical reading of the manuscript.

\section{References}

AHEARN J.N., 1980. Evolution of behavioral reproductive isolation in a laboratory stock of Drosophila silvestris. Experientia, 36, 63-64.

ANDERSON W.W., 1966. Genetic divergence in M. Vetukhiv's experimental populations of Drosophila pseudoobscura. 3. Divergence in body size. Genet. Res., 7, 255-266.

ANNEST J.L., Templeton A.R., 1978. Genetic recombination and clonal selection in Drosophila mercatorum. Genetics, 89, 193-210.

Ayala F.J., Tracey M.L., Barr L.G., McDonald J.F., Perez-Salas S., 1974. Genetic variation in natural populations of five Drosophila species and the hypothesis of the selective neutrality of protein polymorphism. Genetics, 77, 343-384. 
Carson H.L., 1971. Speciation and the founder principle. Stadler Genet. Symp., 3, 51-70.

Carson H.L., 1975. The genetics of speciation at the diploid level. Am. Nat., 109, 83-92.

Carson H.L., Kaneshiro K.Y., 1976. Drosophila of Hawaii : systematics and ecological genetics. Annu. Rev. Ecol., 7, 311-345.

Dobzhansky T., 1941. Genetics and the Origin of Species. Columbia University Press. New York.

Dobzhansky T., Pavlovsky O., 1957. An experimental study of interaction between genetic drift and natural selection. Evolution, 11, 311-319.

DowDEswel. W.H., Ford E.B., 1952. The distribution of spot-numbers as an index of geographic variation in the butterfly Maniola justina L. Heredity, 6, 99-109.

Dowdeswell W.H., Ford E.B., 1953. The influence of isolation on variability in the butterfly Maniola justina L. Symp. Soc. Exp. Biol., 7, 254-273.

Ehrman L., 1964. Genetic divergence in M. Vetukhiv's experimental populations of Drosophila pseudoobscura. 1. - Rudiments of sexual isolation. Genet. Res., 5, 150-157.

FORD E.B., 1954. Problems in the evolution of geographical races. In : HuxLey J., HARDY A.C., Ford E.B. (eds), Evolution as a process, 99-121. George Allen and Unwin, London.

JONES J.S., 1981. Models of speciation. The evidence from Drosophila. Nature, 289, 743-744.

KANESHIRO K.Y., 1980. Sexual isolation, speciation and the direction of evolution. Evolution, 34, 437-444.

MAYR E., 1942. Systematics and the Origin of Species. Columbia University Press. New York.

MAYr E., 1954. Change of genetic environment and evolution. In : HuXley J., Hardy A.C., Ford E.B. (ed.), Evolution as a process, 157-180. George Allen and Unwin, London.

MAYr E., 1970. Population, Speciation and Evolution. Harvard University Press, Cambridge.

MouRaD A.E.K., 1965. Genetic divergence in M. Vetukhiv's experimental populations of Drosophila pseudoobscura. 2. - Longevity. Genet. Res., 6, 139-146.

Mukai T., 1964. The genetic structure of natural populations of Drosophila melanogaster. 1. - Spontaneous mutation rate of polygenes controlling viability. Genetics, 50, 1-19.

Powell J.R., 1978. The founder-flush theory : an experimental approach. Evolution, 32, $465-474$.

Rose M.R., 1982. Antagonistic pleiotropy, dominance, and genetic variation. Heredity, 48, 63-78.

TEMPLETON A.R., 1979. The unit of selection in Drosophila mercatorum. II. - Genetic revolution and the origin of coadapted genomes in parthenogenetic strains. Genetics, 92, $1265-1282$.

Templeton A.R., 1980 a. Modes of speciation and inferences based on genetic distances. Evolution, 34, 719-729.

Templeton A.R., $1980 \mathrm{~b}$. The theory of speciation via the founder principle. Genetics, 94, 1011-1038. 